\title{
Erratum to: Diverging Demography: Hispanic and Non-Hispanic Contributions to U.S. Population Redistribution and Diversity
}

\author{
Kenneth M. Johnson ${ }^{1,2} \cdot$ Daniel T. Lichter ${ }^{3}$
}

Published online: 31 August 2016

(C) Springer Science+Business Media Dordrecht 2016

\section{Erratum to: Popul Res Policy Rev DOI 10.1007/s11113-016-9403-3}

The acknowledgement section was omitted from the original publication of this article. This erratum contains the previously missed acknowledgements.

Acknowledgments Research support for Dr. Johnson was provided by the New Hampshire Agriculture Station under Multi-state Research Project W-3001. Research Assistance was provided by Luke Rogers and Barb Cook.

The online version of the original article can be found under doi:10.1007/s11113-016-9403-3.

Kenneth M. Johnson

ken.johnson@unh.edu

Daniel T. Lichter

DTL28@cornell.edu

1 Department of Sociology, University of New Hampshire, Durham, NH 03824, USA

2 Carsey School of Public Policy, University of New Hampshire, Durham, NH 03824, USA

3 Departments of Policy Analysis and Management and Sociology, Cornell University, Ithaca, NY 14853, USA 